\title{
STUDY OF THE INFLUENCE OF MAGNESIUM HYDROXIDE ON THE COMBUSTIBILITY PERFORMANCE OF POLYMER COMPOSITIONS BASED ON ETHYLENE VINYL ACETATE COPOLYMER
}

\begin{abstract}
Purpose. To obtain the flame retardants polymer compositions for cables tested the effect of use EVA compositions with magnesium hydroxide, on indicators combustibility polymer. Methodology. We used the method of differential scanning calorimetry and defined heat flux dependence on the test time for each composition at temperatures from $20{ }^{\circ} \mathrm{C}$ to $600{ }^{\circ} \mathrm{C}$ rate of temperature rise: $50{ }^{\circ} \mathrm{C} / \mathrm{min}, 75{ }^{\circ} \mathrm{C} / \mathrm{min}, 100{ }^{\circ} \mathrm{C} / \mathrm{min}$. Using the model of free kinetics we determined dependence of the activation energy from the conversion, a dependence of the conversion on the time of the test, the dependence of the time of the conversion from the temperature for each concentration. To comparison of these parameters for each composition we plotted the dependence of the time of the conversion from the temperature and the dependence the degree of conversion from the time of temperature exposure during the combustion of each of the compositions. Results. We obtained the kinetic characteristics, allowing to determine the composition, which provided the best results to reducing the kinetic parameters of flammability of polymeric compositions. Originality. For the first time we used the DSC and model-free kinetics to determine the effect properties of ingredients of the polymer compositions on the combustibility performance. Practical use. The research results can be used to develop polymer compositions for cable products. References 18 , tables 3 , figures 9.
\end{abstract}

Key words: ethylene vinyl acetate copolymer, magnesium hydroxide, combustibility, polymeric composition, kinetics.

Цель. Целью статьи является определение влияния дигидрата оксида магния на показатели горючести полимерных композиций на основе сополимера этилена с винилацетатом для разработки составов полимерных композиций для кабельной продукции с повыщенными требованиями по пожсарной безопасности. Методика. Мы применили метод дифференциальной сканирующей калориметрии (ДСК) и определили зависимость теплового потока от времени испытания для каждого состава при температурах от $20{ }^{\circ} \mathrm{C}$ до $600{ }^{\circ} \mathrm{C}$ и разной скорости подъема температуры: $50{ }^{\circ} \mathrm{C} /$ мин, $75{ }^{\circ} \mathrm{C} /$ мин, $100{ }^{\circ} \mathrm{C} /$ мин. Используя модель свободной кинетики определили зависимость энергии активации от степени превращения, зависимость степени превращения от времени испытания, зависимость времени превращения от температуры для каждой концентрации. Для сравнения этих показателей для каждой композиции строили графики зависимости времени превращения от температуры и зависимости степени превращения от времени воздействия температуры при сгорании каждой из композиций. Результаты. Получены кинетические характеристики, позволяющие определить состав, обеспечивающий лучиие результаты по сниэению кинетических показателей горючести полимерных композиций. Научная новизна. Впервые мы использовали ДСК и модель свободной кинетики для определения влияния свойств ингредиентов полимерных композиций на показатели горючести. Практическое применение. Результаты исследований могут быть использованы при разработке полимерных композиций для кабельной продукции. Библ. 18, табл. 3, рис. 9.

Ключевые слова: сополимер этилена с винилацетатом, дигидрат оксида магния, горючесть, полимерная композиция, кинетика.

\section{Introduction.}

Increasing the fire safety requirements for polymer compositions for the manufacture of cable products is given increasing importance due to the increasing application of the latter in a wide variety of technical and economic fields and tougher requirements for fire safety in construction, energy, nuclear energy, railway transport [1-4].

One of the ways to reduce the combustibility of polymer materials based on polyolefins is the introduction of filler-flame retardants into the polymer composition. Inorganic fillers-fire retardants, in particular magnesium hydroxides are used. These materials not only increase fire resistance by absorbing a large amount of heat, but also neutralize acid gases, which leads to a reduction in smoke formation [5-9].

The heating of polymeric materials to temperature at which a sharp increase in the rate of exothermic oxidation reactions takes place, results in the appearance of smoldering. Smoldering is the flameless burning of a solid material at relatively low temperatures (400-600) ${ }^{\circ} \mathrm{C}$ often accompanied by the emission of smoke.

The cable products are required to meet the burning performance: an exothermic reaction with an oxidizer, heat of combustion, combustion temperature, energy of heat release, burning rate. Data on these parameters for polymer compositions based on the ethylene-vinyl acetate copolymer and magnesium oxide are absent [10, 11]. Therefore, it is expedient to investigate these processes when developing and assessing the fire hazard of polymer materials for cable products.

The goal of investigations is study of the effect of magnesium dihydrates on the flammability of polymer compositions based on ethylene vinyl acetate copolymer.

Experimental investigations.

Carrying out investigations we used ethylene copolymers with vinyl acetate (CVA), the characteristics of which are given in Table 1.

Table1

CVA characteristics

\begin{tabular}{|l|c|c|}
\hline \multicolumn{1}{|c|}{ Indicator name } & CVA 1 & CVA 2 \\
\hline Density, $\mathrm{kg} / \mathrm{m}^{3}$ & 939 & 951 \\
\hline $\begin{array}{l}\text { Melt flow index, } \\
2.16 \mathrm{~kg}, \mathrm{~g} / 10 \mathrm{~min}\end{array}$ & 2.5 & 5 \\
\hline Content of vinyl acetate, \% & 18 & 28 \\
\hline
\end{tabular}

(C) E.V. Chuleyeva, V.M. Zolotaryov 
Magnesium dihydrates the characteristics of which are given in Table 2 were they used as retardants fillers.

Table 2

Characteristics of retardant fillers

\begin{tabular}{|l|c|c|}
\hline \multirow{2}{*}{ Name of indicators } & \multicolumn{2}{|c|}{$\mathrm{Mg}(\mathrm{OH})_{2}$} \\
\cline { 2 - 3 } & Sample No. 1 & Sample No. № 2 \\
\hline $\mathrm{Mg}(\mathrm{OH})_{2}$ & $>93$ & $>93.2$ \\
\hline $\mathrm{SiO}_{2}$ & $<0.05$ & $2.2 \pm 0.2$ \\
\hline $\mathrm{Fe}_{2} \mathrm{O}_{3}$ & $<0.3$ & $0.12 \pm 0.02$ \\
\hline $\mathrm{Na}_{2} \mathrm{O}$ & $<0.05$ & - \\
\hline $\mathrm{CaO}$ & - & $2.2 \pm 0.2$ \\
\hline \multicolumn{3}{|c|}{ Median particle diameter, $\mu$ m: } \\
\hline average $\left(D_{50}\right)$ & 3.0 & 3.7 \\
\hline maximal $\left(D_{98}\right)$ & 20.0 & 12.5 \\
\hline minimal $\left(D_{10}\right)$ & 1.0 & 1.1 \\
\hline
\end{tabular}

Polymer compositions are presented in Table 3.

Table 3

Polymer compositions

\begin{tabular}{|c|c|c|c|c|}
\hline \multirow{3}{*}{ 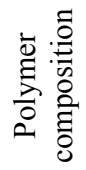 } & \multicolumn{4}{|c|}{ Components, \% } \\
\hline & CVA 1 & CVA? & $\mathrm{Mg}(\mathrm{OH})_{2}$ & $\mathrm{Mg}(\mathrm{OH})_{2}$ \\
\hline & & & Sample No. 1 & Sample No. 2 \\
\hline $1 \mathrm{a}$ & 60 & & 40 & \\
\hline $2 \mathrm{a}$ & & 60 & 40 & \\
\hline $3 a$ & 60 & & & 40 \\
\hline $4 a$ & & 60 & & 40 \\
\hline $1 b$ & 50 & & 50 & \\
\hline $2 b$ & & 50 & 50 & \\
\hline $3 b$ & 50 & & & 50 \\
\hline $4 b$ & & 50 & & 50 \\
\hline $1 \mathrm{c}$ & 40 & & 60 & \\
\hline $2 \mathrm{c}$ & & 40 & 60 & \\
\hline $3 \mathrm{c}$ & 40 & & & 60 \\
\hline $4 c$ & & 40 & & 60 \\
\hline
\end{tabular}

Thermal, temperature and kinetic characteristics were determined from the data obtained on the TGA/DSC 1/1100 SF device for differential scanning calorimetry from METTLER TOLEDO Company at temperature from $20{ }^{\circ} \mathrm{C}$ to $650{ }^{\circ} \mathrm{C}$ and heating rate $(\beta)$ of $50{ }^{\circ} \mathrm{C} / \mathrm{min}$, $75^{\circ} \mathrm{C} / \mathrm{min}$ and $100{ }^{\circ} \mathrm{C} / \mathrm{min}$.

Differential scanning calorimetry is based on the well-known principle of Boersma, or the principle of heat flow, in accordance with which the heat fluxes of the sample and the reference measurement are compared.

TGA/DSC 1 is a highly sensitive measuring instrument of thermogravimetric analysis (TGA). The main node TGA/DSC 1 is a measuring cell which includes a furnace and a balance. In addition to the mass of the sample, which is measured with the built-in highprecision balance, TGA/DSC 1 provides a sample temperature measurement. Together with the value of the reference temperature, these values form the basis of the thermogravimetric analysis of the sample. In addition, TGA/DSC 1 allows the measurement of the heat flux signal, thereby providing the use of differential scanning calorimetry (DSC). The sample temperature and the heat flux signal are determined based on the readings of the temperature sensors, which is measured directly with a thermocouple mounted in the crucible holder.

The heat flux is calculated from the DTA (differential thermal analysis) signal, which is the difference between the sample temperature and the temperature set in the temperature program. The module transmits the measurement data to the software, which determines the amount of heat flow from the formulas:

$$
\begin{gathered}
\varphi=E_{(T)} S D T A, \\
S D T A=T_{S}-T_{\text {set }},
\end{gathered}
$$

where $\varphi$ is the heat flux, $E_{(T)}$ is the calorimetric sensitivity, $T_{s}$ is the measured sample temperature, $T_{\text {set }}$ is the temperature value given in the temperature program [12].

Kinetic calculations were performed using the model of free kinetics [13-18]. The model of free kinetics is based on the temperature dependence and the degree of transformation. Each transformation gives the calculated value of the activation energy. The reaction rate for a fixed degree of conversion depends only on temperature. The Arrhenius temperature function is used.

For the analysis, three dynamic temperature curves were used for each polymer composition (Fig. 1). Dynamic, isothermal and combined temperature programs were used.

The processing of kinetic experiments is based on the theoretical equation of S. Vyazovkin:

$$
\frac{d \alpha}{d t}=k e^{-E / R T} f(\alpha)
$$

where $\frac{d \alpha}{d t}$ is the reaction speed, $\mathrm{s}^{-1} ; k$ is the speed constant; $E$ is the activation energy, $\mathrm{J} / \mathrm{mol} ; R$ is the universal gas constant, $\mathrm{J} /(\mathrm{mol} \times \mathrm{K}) ; T$ is the temperature, $\mathrm{K} ; \alpha$ is the degree of transformation, $\%$.

The activation energy $E(\alpha)$ is constant for a certain degree of transformation (the isoconversion method).

The rate of chemical reaction depends on the degree of transformation $(\alpha)$, temperature $(T)$ and time $(t)$. The reaction speed depends on the degree of transformation $f(\alpha)$. For each process, speed is own and is determined experimentally.

Based on the DSC obtained using the above programs, we obtain graphical data on the dependence of the activation energy $E(\alpha)$ on the degree of conversion (in our case, the degree of combustion); the dependence of the degree of transformation $(\alpha)$ on the test time $(t)$ at fixed temperature $(T)$ and the dependence of the transformation time $(\mathrm{t})$ on temperature at fixed degree of transformation $(\alpha)$ (Fig. 1). 


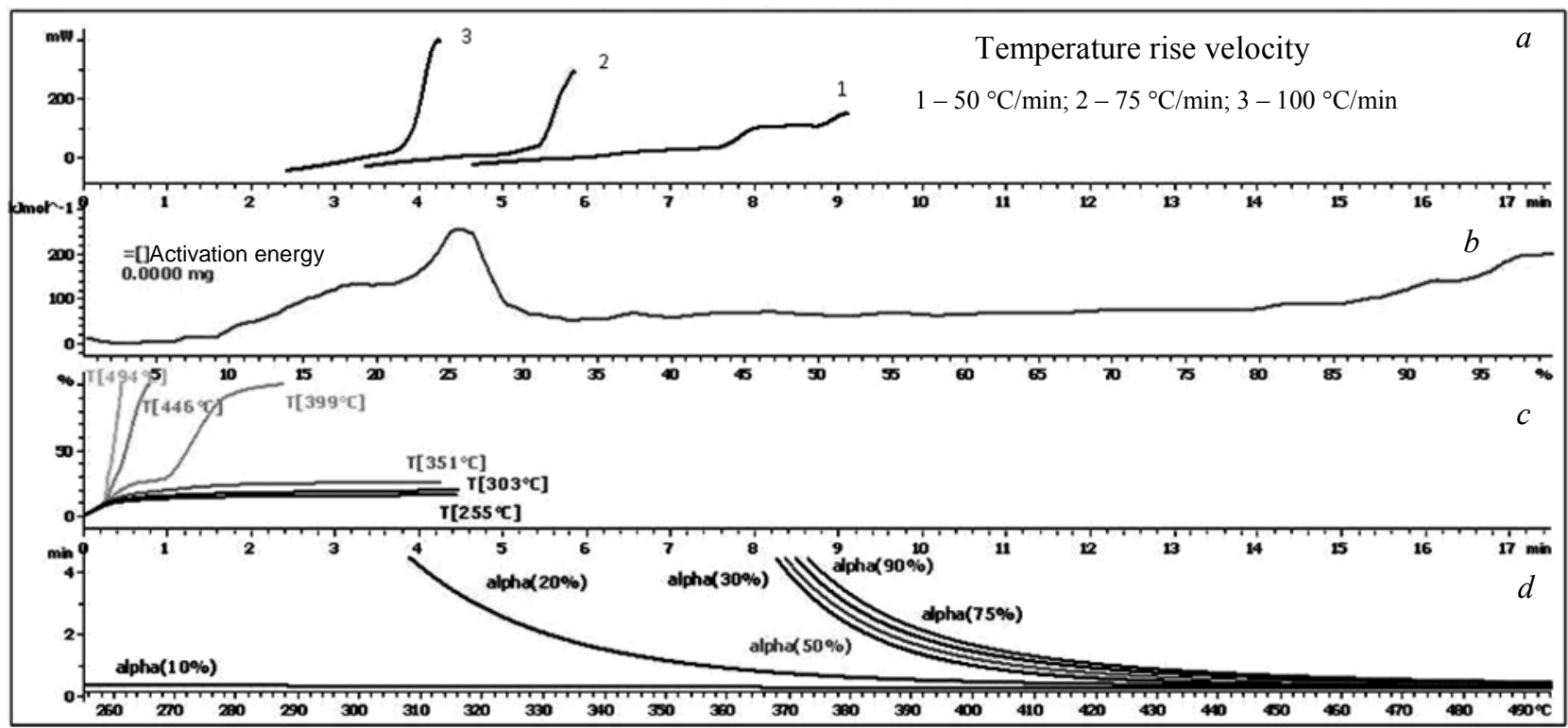

Lab: METTLER

Fig. 1. Thermal, temperature and kinetic characteristics:

$a$ - the dependence of the heat flux on the test time;

$b$ - dependence of the activation energy on the degree of transformation;

$c$ - dependence of the degree of transformation on the test time;

$d$-dependence of the transformation time on temperature

To determine the effect of the ingredients of the polymer compositions on the kinetic characteristics, graphs were constructed of the dependence of the transformation time on temperature at a constant conversion degree $(\alpha=75 \%)$. The results are shown in Fig. 2-5.

From the analysis of the obtained data it follows that the kinetic characteristics of the polymer compositions essentially depend on the properties of both CVA 1 and CVA 2 as well as fillers.

The transformation time decreases when exposed to elevated temperatures. At the same time, in the temperature range close to combustion temperatures $\left(430{ }^{\circ} \mathrm{C}\right)$, the conversion time is higher for the polymer

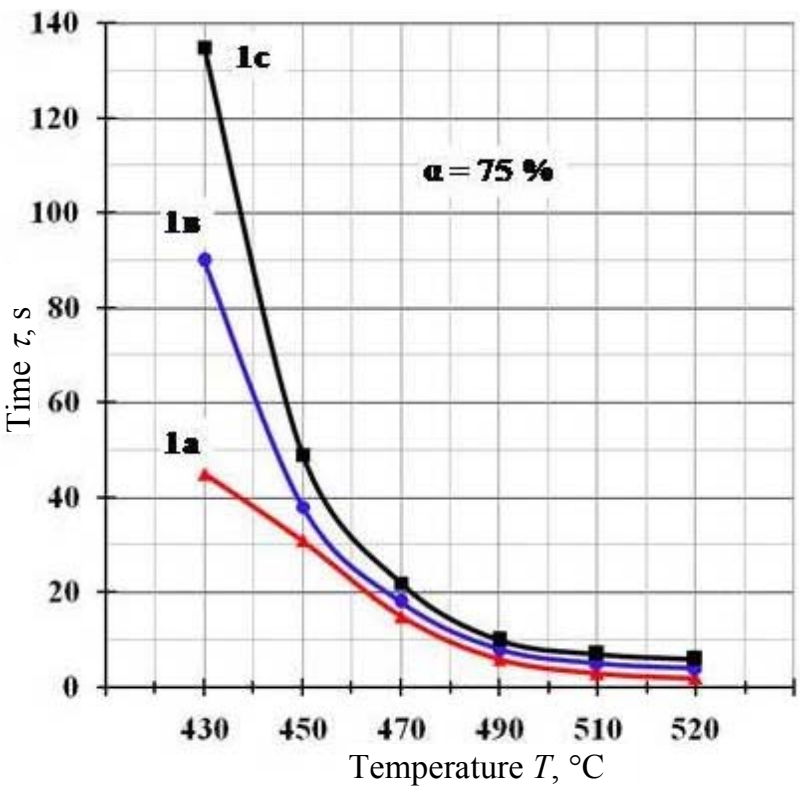

Fig. 2. Dependence of the transformation time on temperature for polymer compositions 1a, 1b, 1c composition based on CVA 1 and flame retardant (sample No. 1). As the temperature rises to $520^{\circ} \mathrm{C}$, the transformation time decreases.

An analogous dependence is observed for polymer compositions based on CVA 2.

However, the transformation time is of greater importance than for CVA 1 based polymer compositions.

The dependence of the degree of conversion on the time of exposure to an elevated temperature close to the combustion temperature of polymer compositions was studied.

For this purpose, graphical dependencies of these characteristics were constructed at a temperature of $440{ }^{\circ} \mathrm{C}$ (Fig. 6-9).

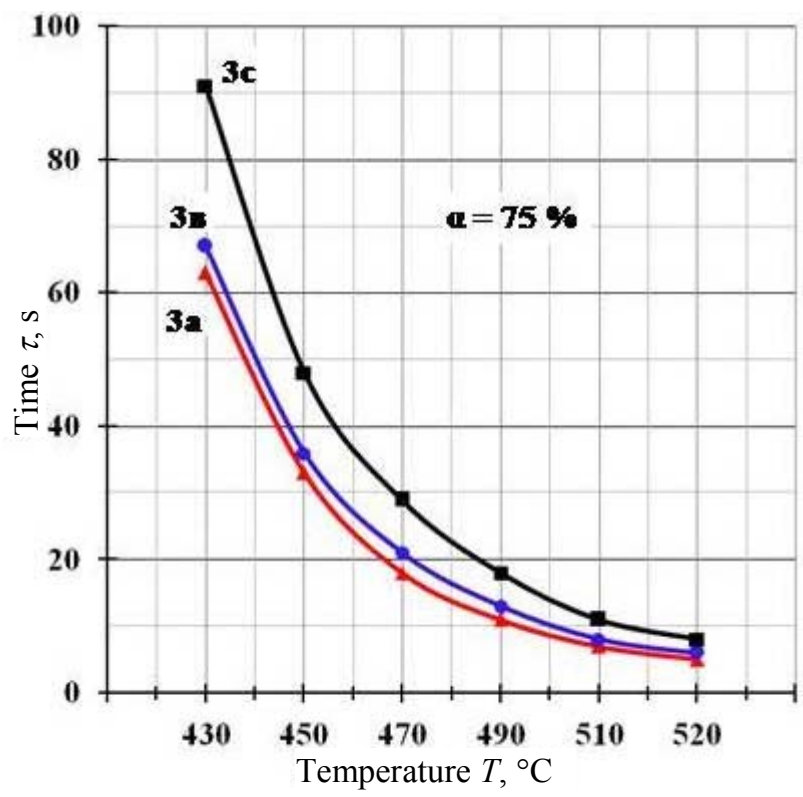

Fig. 3. Dependence of the transformation time on temperature for polymer compositions $3 \mathrm{a}, 3 \mathrm{~b}, 3 \mathrm{c}$ 


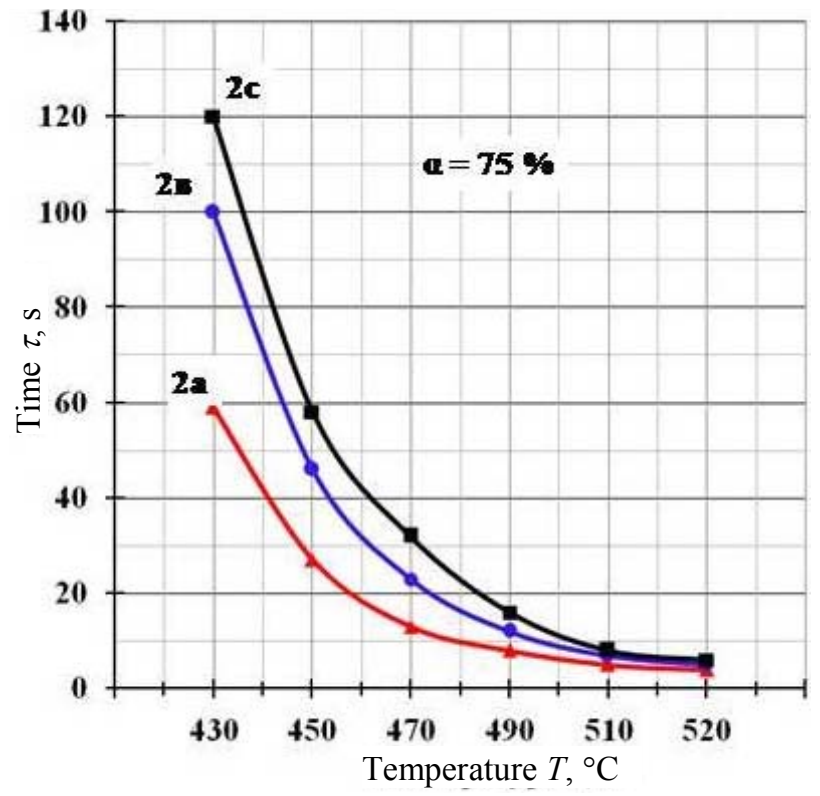

Fig. 4. Dependence of the transformation time on temperature for polymer compositions $2 \mathrm{a}, 2 \mathrm{~b}, 2 \mathrm{c}$

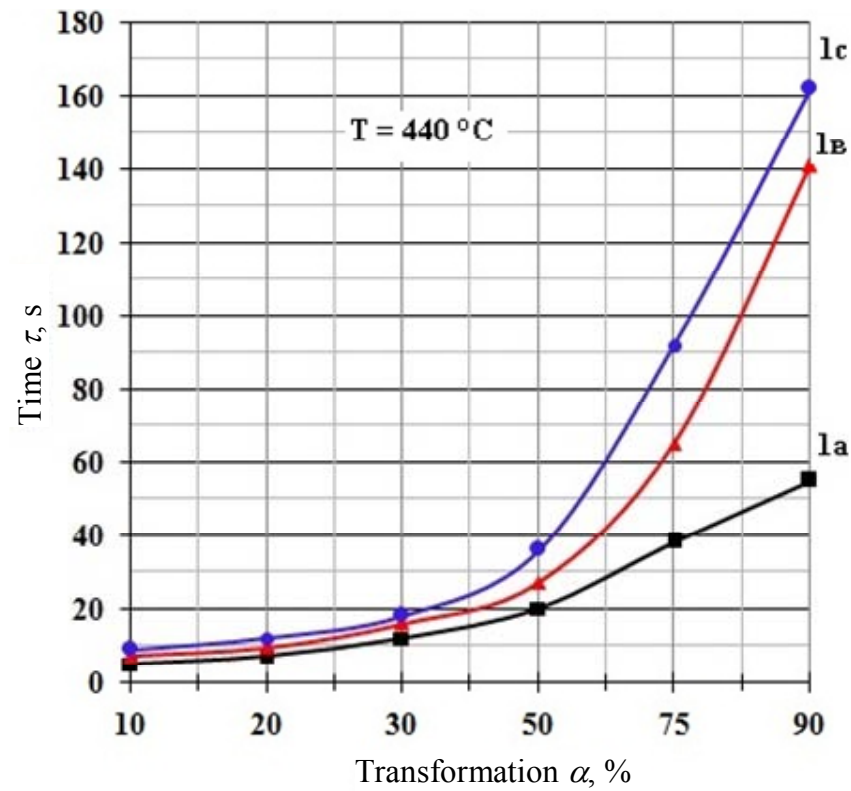

Fig. 6. Dependence of the degree of transformation on the temperature influence time for compositions $1 \mathrm{a}, 1 \mathrm{~b}, 1 \mathrm{c}$

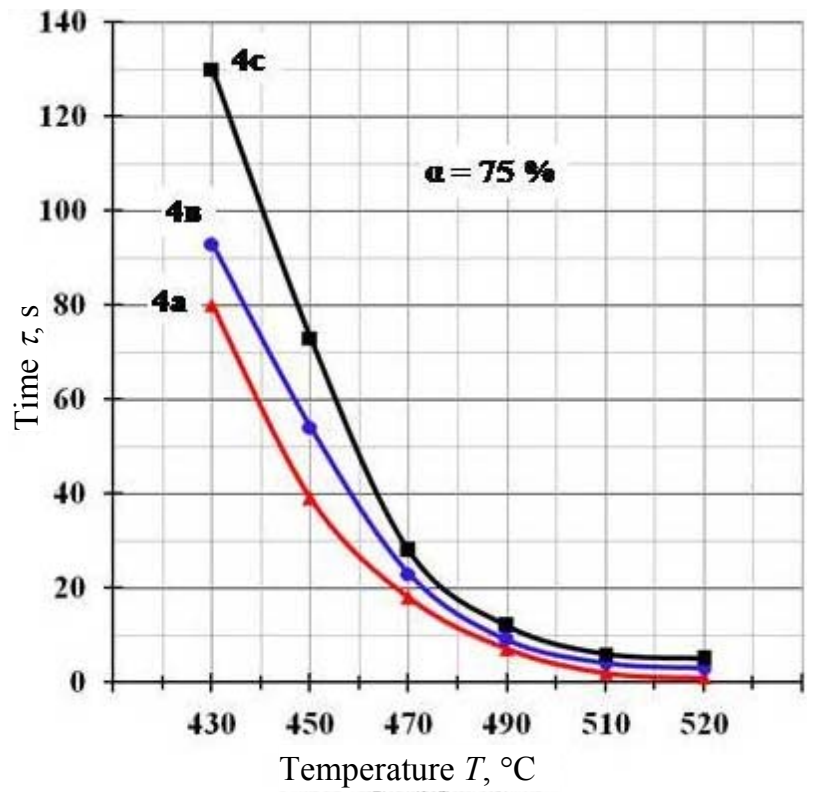

Fig. 5. Dependence of the transformation time on temperature for polymer compositions $4 \mathrm{a}, 4 \mathrm{~b}, 4 \mathrm{c}$

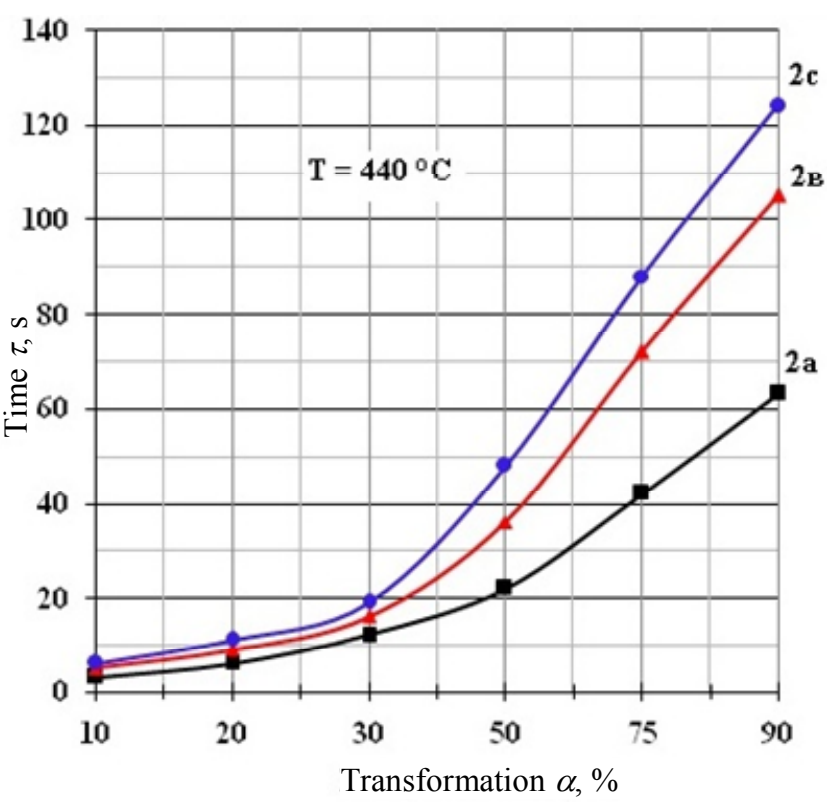

Fig. 7. Dependence of the degree of transformation on the temperature influence time for compositions $2 \mathrm{a}, 2 \mathrm{~b}, 2 \mathrm{c}$ 


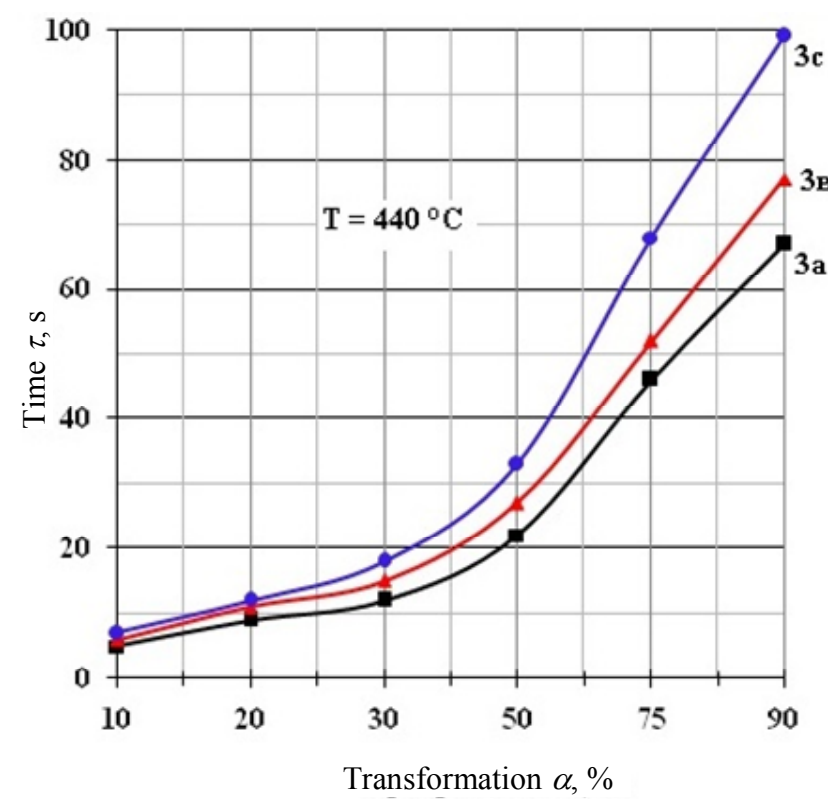

Fig 8. Dependence of the degree of transformation on the temperature influence time for compositions $3 \mathrm{a}, 3 \mathrm{~b}, 3 \mathrm{c}$

From the data presented, it follows that the degree of transformation $\alpha$ increases with the time of exposure to an elevated temperature.

In this case, the exposure time should be significantly increased for polymer compositions based on CVA 2 and filler (sample No. 2).

\section{Conclusions.}

1. Kinetic characteristics are obtained for polymer compositions based on CVA using magnesium oxide dihydrate as an excipient for retardant.

2. The composition based on CVA2 (with high content of vinyl acetate and a high melt flow index) with a filler (sample No. 2) with smaller maximum particle diameter and largest content of $\mathrm{SiO}_{2}$ guarantees better results to reduce flammability indicators.

\section{REFERENCES}

1. DSTU EN 50363-7:2010. Materialy dlya izolyatsiyi, obolonok i zovnishnikh pokryviv nyz'konapruzhnykh sylovykh kabeliv. Chastyna 7. Bez-halohenni termoplastychni izolyatsiyni kompozytsiyi [State Standard of Ukraine EN 50363-7:2005. Insulating, sheathing and covering materials for low voltage energy cables. Part 7: Halogen-free, thermoplastic insulating compounds]. Kyiv, 2013. p. 4. (Ukr).

2. DSTU EN 50363-5:2010. Materialy dlya izolyatsiyi, obolonok i zovnishnikh pokryviv nyz'konapruzhnykh sylovykh kabeliv. Chastyna 5. Bez-halohenni vulkanizovani izolyatsiyni kompozytsiyi [State Standard of Ukraine EN 50363-5:2005. Insulating, sheathing and covering materials for low voltage energy cables. Part 5: Halogen-free, cross-linked insulating compounds]. Kyiv, 2013. p. 4. (Ukr).

3. DSTU EN 50363-6:2010. Materialy dlya izolyatsiyi, obolonok i zovnishnikh pokryviv nyz'konapruzhnykh sylovykh kabeliv. Chastyna 6. Bez-halohenni vulkanizovani kompozytsiyi obolonok [State Standard of Ukraine EN 50363-

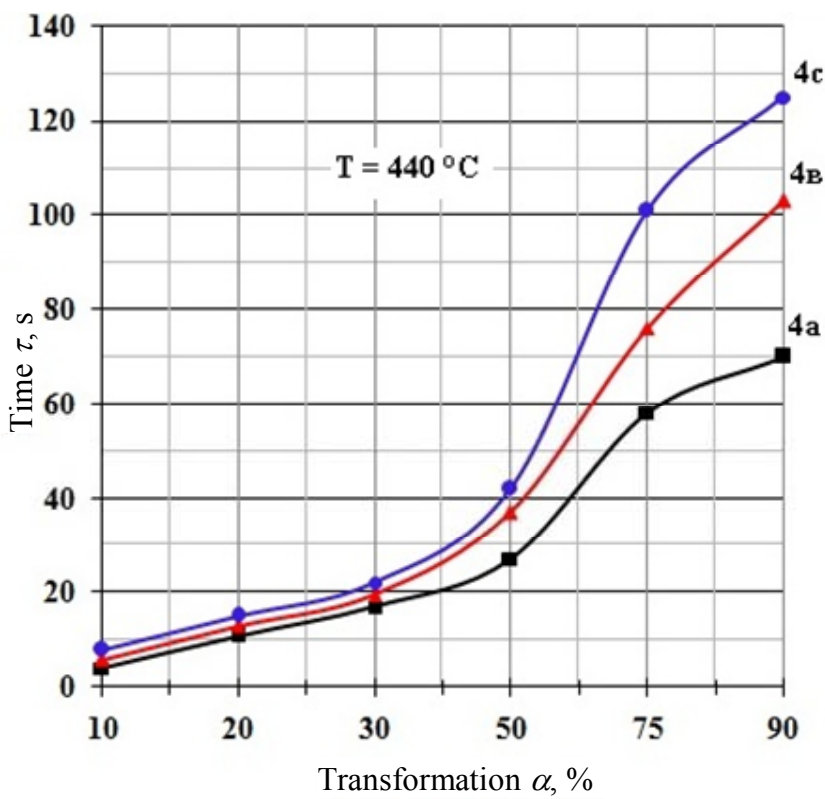

Fig. 9. Dependence of the degree of transformation on the temperature influence time for compositions $4 \mathrm{a}, 4 \mathrm{~b}, 4 \mathrm{c}$

6:2005. Insulating, sheathing and covering materials for low voltage energy cables. Part 6: Halogen-free, cross-linked sheathing compounds]. Kyiv, 2013. p. 4. (Ukr).

4. Peshkov I.B. Materialy kabel'nogo proizvodstva [Materials of cable production]. Moscow, Mashinostroenie Publ., 2013. 456 p. (Rus).

5. Tirelli D. Flame retardants for composites. The Chemical Journal, 2013, no.1-2, pp. 42-45. (Rus).

6. Overview mineral flame retardants, halogen-free cable for hydroxide compositions. Kabel-News, 2009, no.8, pp. 41-43. (Rus).

7. Mikhalin Y.A. Criteria of plastics fire resistance and methods of their testing. Polimernye materialy, 2011, no.7, pp. 26-31. (Rus).

8. Herbiet R. Mineral Flame Retardants: Market Outlook and Latest Developments. High Performance Filler, 2005, pap. 4, p. 20.

9. Innes J., Innes A. Plastic Flame Retardants: Technology and Current Developments. Rapra Review Reports, 2004, vol.14, no.12, report 168, p. 148.

10. EN 13501-6:2014 (E) Fire classification of construction products and building elements - Part 6: Classification using data from reaction to fire tests on electric cables.

11. EN 50399:2011 Common test methods for cables under fire conditions -Heat release and smoke production measurement on cables during flame spread test -Test apparatus, procedures, results.

12. $\mathrm{STAR}^{\mathrm{e}}$ thermal analysis system, operating instructions to the TGA/DSC 1. Switzerland, Mettler Toledo AG, 2007.

13. Tips on model free kinetics. METTLER TOLEDO Thermal Analysis UserCom 8, 1998, pp. 1-3.

14. Vyazovkin S., Wight C.A. Model-free and model-fitting approaches to kinetic analysis of isothermal and nonisothermal data. Thermochimica Acta, 1999, no.340-341, pp. 53-68. doi: 10.1016/S0040-6031(99)00253-1.

15. Vyazovkin S. What can model free kinetics tell us about reaction mechanisms? METTLER TOLEDO Thermal Analysis UserCom.10, 1999, pp. 9-10. 
16. Schawe J. Kinetic studies of complex reactions. Part 1: model free kinetics. METTLER TOLEDO Thermal Analysis UserCom 18, 2003, pp. 13-16.

17. Varankina G.S., Vysotskii A.V. Effective low toxic aluminosilicate fillers for phenol formaldehyde adhesives for plywood and particleboard. Adhesives in woodworking Industry, 1997, pp. 114-120.

18. Vyazovkin S. Evaluation of activation energy of thermally stimulated solid-state reactions under arbitrary variation of temperature. Journal of Computational Chemistry, 1997, vol.18, no.3, pp. 393-402. doi: 10.1002/(SICI)1096987X(199702)18:3<393::AID-JCC9>3.0.CO;2-P.

\section{Received 10.01.2017}

How to cite this article:

Chuleyeva E.V., Zolotaryov V.M. Study of the influence of magnesium hydroxide on the combustibility performance of polymer compositions based on ethylene vinyl acetate copolymer. Electrical engineering \& electromechanics,

2017, no.2, pp. 43-48. doi: 10.20998/2074-272X.2017.2.07.
E.V. Chuleyeva ${ }^{1}$, Candidate of Technical Science,

V.M. Zolotaryov ${ }^{1}$, Doctor of Technical Science,

${ }^{1}$ Private Joint-stock company Yuzhcable works,

7, Avtogennaya Str., Kharkiv, 61099, Ukraine,

phone +380 577545312 ;

e-mail: echuleeva@mail.ru 